DOI 10.31392/NPU-nc.series 15.2021.3(133).01

\author{
Kocha Inna \\ candidate of Pedagogics, Senior Lecturer of the \\ department of theory and methods of preschool education, primary education and speech communication of \\ Municipal higher education institution"Kherson Academy of Continuing Education» \\ Mykola Halaidiuk \\ Ph.D in Physical Education and Sports, Associate Professor of the Department of Physical Education, \\ Kotsyubynskyi Vinnitsa State Pedagogical University \\ Alla Heta \\ Ph.D in Physical Education and Sports, \\ Associate Professor of the Department of Social Work and Special Education, \\ Poltava Institute of Economics and Law \\ Vasyll Sharodi \\ Senior lecturer of the Department of Physical Education, State University "Uzhhorod National University" \\ Olha Kravchenko \\ Lecturer of the Department of Physical Education, State University "Uzhhorod National University" \\ Olga Dudash \\ Assistant of the Department of Physical Education, State University "Uzhhorod National University"
}

\title{
A HEALTHY LIFESTYLE OF YOUNGER SCHOOLCHILDREN: RETROSPECTIVE ANALYSIS
}

Such aspects as an over-use of modern information technologies, low physical activity of younger schoolchildren, destruction of their axiological knowledge and age-related functional changes in their body systems have negatively affected their health. Consequently, the problem of promoting a healthy lifestyle among primary school pupils as one of the key competencies specified in the State Standard for Primary Education remains rather relevant. This research aims to reveal the content, forms and methods of promoting a healthy lifestyle among primary school pupils in the second half of the 20th century - the early 21 st century based on comprehensive retrospective analysis and identify the main areas of applying certain constructive experience in today's education. Besides, it presents the results obtained from a comprehensive study of promoting a healthy lifestyle among primary school pupils (the second half of the 20th century - the early 21st century) based on an analysis of scientific literature, archival sources, as well as relevant theory and practice. It specifies such basic concepts as "health", "healthy lifestyle", "promoting a healthy lifestyle" and "promoting a healthy lifestyle among primary school pupils". Also, it identifies those factors (socio-economic, educational, health- and hygiene-related, socio-cultural) that have influenced the promotion of a healthy lifestyle among younger children in the period under study. It justifies the author's periodization of promoting a healthy lifestyle among primary school pupils from the 1950s to the early 21st century (2017), which consists of the following three stages: Stage 1 (1950-1969) -the preparatory stage; Stage 2 (1970-1990) - the transformational stage; Stage 3 (1991-2017) - the updating stage. The research also suggests the ways of using ideas of the historical and pedagogical experience in promoting a healthy lifestyle among primary school pupils in the context of today's reforms in education.

Keywords: health, promoting a healthy lifestyle, primary school pupils, younger schoolchildren.

Коча І. А. Галайдюк М. А., Гета А. В., Шароді В.М., Кравченко О.Б., Дудаш О.В. Здоровий спосіб життя учнів молодшого шкільного віку: ретроспективний аналіз. Надмірне використання сучасних інформаційних технологій, зменшення рухової активності школярів, деструкція в ціннісній свідомості, вікові фуннціональні зміни в діяльності різних систем організму, особливо учнів молодшого шкільного віку, спричинили погіршення стану здоров'я дітей. Саме тому актуалізується проблема формування здорового способу життя учнів початкової школи як однієї $з$ ключових компетентностей, зазначених у Державному стандарті початкової освіти. Мета дослідження - на основі иілісного ретроспективного аналізу розкрити зміст, форми і методи фрормування здорового способу життя учнів початкової школи в другій половині $X X$ - на початку XXI століття та визначити основні напрями екстраполяції конструктивного досвіду в сучасну освітню галузь. На основі вивчення наукової літератури, архівних джерел, аналізу теорії та практики здійснено комплексне дослідження формування здорового способу життя учнів початкової школи (друга половина XX - початок XXI століття). Окреслено сутність базових дефрініцій, а саме: «здоров'я», «здоровий спосіб життя», «формування здорового способу життя» та визначено поняття «формування здорового способу життя учнів початкової школи». Виявлено чинники (соціально-економічні, освітні, медико-гігієнічні, соціокультурні), що впливали на формування здорового способу життя молодших школярів у досліджуваний період. Обгрунтовано авторську періодизацію формування здорового способу життя учнів початкової школи з 1950 р. до початку XXI століття (2017 рік), що містить mри періоди: I період (1950-1969 рр.) - організаційний; II період (1970-1990 рр.) - ресрормаційний; III період (1991-2017 рр.) - модернізаційний. Окреслено перспективні напрями застосування ідей історико-педагогічного досвіду щодо формування здорового способу життя учнів початкової школи в контексті сучасних освітніх рефрорм.

Ключові слова: здоров'я, формування здорового способу життя, учні початкової школи, молодші школярі.

Problem statement. Today's society aims to modify certain social values, including a concern for health and harmonious development of future generations. The leading factors in such changes involve an ecological imbalance and pollution, a standard production of poor-quality products, an increasing share of intellectual labour in the economic sector causing physical inactivity. 
These processes make scientific studies on health rather relevant. Particular attention should be paid to the promoting of a healthy lifestyle among primary school pupils since an early age contributes to teaching children to care for their health and keep a healthy lifestyle.

At the same time, such aspects as an over-use of modern information technologies, low physical activity of younger schoolchildren, destruction of their axiological knowledge and age-related functional changes in their body systems have negatively affected their health. Therefore, the problem of promoting a healthy lifestyle among primary school pupils as one of the key competencies specified in the State Standard for Primary Education remains rather relevant.

Analysis of topical researches. Such research as M. Babych (2006), Y. Pivnenko (2013), O. Pysarchuk (2014), 0. Vashchenko (2007), O. Yankovych (2017) study the problems of preserving and promoting health in primary school. I. Roshchin (2015) and T. Chyzhyk (2018) analyze historical and pedagogical aspects of promoting a healthy lifestyle among schoolchildren [17].

A retrospective analysis shows that the second half of the $20^{\text {th }}$ century - the early 21 st century is a period during which the content, forms and methods of promoting a healthy lifestyle among primary school pupils began to be studied not only in the field of history of pedagogy, theory and methods of physical education (Chyzhyk, 2018; Dubohai, 2006; Moiseiev, 2009; Roshchin, 2015; Shyian, 2008; Zakopailo, 2003; Zubalii, 2000) but also medicine and school hygiene (Akhverdova, 2004; Amosov, 1987; Apanasenko, \& Dolzhenko, 2007; Brekhman, 1990; Hundarov, 1999; Khripkova, Antropova, \& Farber 1990; Kondratiuk, 2003) [619].

An analysis of scientific and methodological sources concludes that the second half of the $20^{\text {th }}$ century had witnessed significant changes in the promotion of a healthy lifestyle among pupils, especially younger schoolchildren. However, there have been no comprehensive studies on this problem thus far.

Taking into account the multi-faceted nature of health, this research interprets the promotion of a healthy lifestyle among primary school pupils a complex process, focused on the development of children's vital competence, cultivation of their valuesbased attitude towards their health, as well as the creation of relevant conditions for maintaining and strengthening physical, mental, spiritual and social spheres of pupils' health during the educational process in primary school.

A historical-and-pedagogical study of scientific literature shows that there are many studies on the history of pedagogy, physical education which attempt to define and justify the periods (stages) of the establishment, functioning and promotion of a healthy lifestyle among schoolchildren [7; 20-37]. Taking into account the characteristic trends in physical training of younger schoolchildren (Chyzhyk, 2018)), relying on the periodization of promoting a healthy lifestyle among younger schoolchildren in pedagogical practice and science (Chernii, 2014) and theoretical analysis of legal documents and holistic studies on the characteristics of the content, forms and methods of health promotion in primary school, one can distinguish the following three stages: Stage 1 (1950-1969) - the preparatory stage (the first sub-stage - 1950-1959; the second sub-stage - 1960-1969); Stage 2 (1970-1990) - the transformational stage (the first sub-stage - 1970-1983; the second sub-stage - 1984-1990); Stage 3 (19912017 ) - the updating stage (the first sub-stage - 1991-2001; the second sub-stage - 2002-2017). Each period has its chronological boundaries, caused by socio-economic, educational, medical and hygienic, socio-cultural factors, as well as a gradual evolution of the content, forms and methods for promoting a healthy lifestyle among primary school children [7; 20].

Historical and pedagogical studies make little effort to search for ways of promoting a healthy lifestyle among pupils in the field of pedagogical, cultural and valeological education, which does not show a real picture of scientific views on this problem.

It is vital to study the historical and pedagogical experience in promoting a healthy lifestyle among primary school pupils in the second half of the $20^{\text {th }}$ century - the early 21 st century. This period is characterized by the elaboration and implementation of relevant legal documents, as well as the justification of the content, forms and methods for promoting a healthy lifestyle. Despite a wide range of studies, this period remains poorly studied and therefore requires further scholarly exploration.

This research aims to reveal the content, forms and methods of promoting a healthy lifestyle among primary school pupils in the second half of the $20^{\text {th }}$ century - the early 21 st century based on comprehensive retrospective analysis and identify the main areas of applying certain constructive experience in today's education.

Presentation of the main material. The research employs the following theoretical methods: comparative analysis (a comparison of theoretical and psycho-pedagogical approaches to solving this problem and clarifying concepts and terms; theory and practice of promoting a healthy lifestyle among primary school pupils at different stages of education development in diachrony), system-historical (consideration of historical prerequisites for updating the content, forms and methods of forming a healthy way of life of students), a systemic-and-historical analysis (a consideration of historical prerequisites for updating the content, forms and methods for promoting a healthy lifestyle among pupils); special scientific methods: chronological order (a study of the process of promoting a healthy lifestyle in primary school and its periodization); bibliographic search (a systematization and classification of philosophical, psycho-pedagogical and methodical literature, archival materials, documents, periodicals on the problem of promoting a healthy lifestyle in primary school); critical analysis of scientific and methodological literature, practical experience (a study, systematization and generalization of Ukrainian experience of promoting a healthy lifestyle among younger schoolchildren), empirical methods (a study of documents for identifying the characteristics of preserving and promoting children' health in different historical periods); structural-and-systemic analysis of the content, forms, methods and teaching aids (a generalizion of findings and their interpretation with respect to modern primary education; an outline of opportunities for creative use of the acquired experience in promoting a healthy lifestyle among younger pupils).

The sources of the research include both published and unpublished materials from the Central State Archives of Higher Authorities and Administration of Ukraine, the State Archives of Kherson Oblast, scientific works and publications of the prominent Ukrainian and international researches in the second half of the $20^{\text {th }}$ century - the early 21 st century (monographs, dissertations); legal acts, memorandums, proceedings of congresses, conferences, curricula, educational literature published in the period under study; holdings of such libraries as Vernadsky National Library of Ukraine, V. O. Sukhomlynskyi State Scientific and Pedagogical 
Library, O. Honchar Kherson Regional Universal Scientific Library; Ukrainian historical-and-pedagogical and psycho-pedagogical literature published in the period under study and nowadays; Internet resources covering the problems of developing primary school and pedagogical views of Ukrainian researchers on the promotion of a healthy lifestyle among primary school pupils.

Chronological boundaries of the research cover the second half of the $20^{\text {th }}$ century - the early 21 st century. The lower chronological boundary is related to the adoption of the resolution of the Council of Ministers of the Union of Soviet Socialist Republics and the Central Committee of the Communist Party No 2511 as of August 17, 1950 "On the Regulation of Internal Order and Daily Routine of Pupils in Primary, Seven-Year and Secondary Schools of the USSR". This resolution defined a new paradigm of strengthening pupils' health and promoting a healthy lifestyle among primary school pupils in the post-war years.

The upper chronological boundary (2017) can be explained by the adoption of the Law of Ukraine "On Education" and the implementation of the New Ukrainian School Concept, which have made significant changes in the functioning of primary school, including updating the very field and integrating the content, forms and methods for promoting a healthy lifestyle among primary school pupils.

The preparatory stage covers the years 1950 to 1969 (the first sub-stage - 1950-1959; the second sub-stage - 19601969). After the adoption of the resolution of the Council of Ministers of the Union of Soviet Socialist Republics and the Central Committee of the Communist Party No 2511 as of August 17, 1950 "On the Regulation of Internal Order and Daily Routine of Pupils in Primary, Seven-Year and Secondary Schools of the USSR", Soviet authorities started to promote physical education and mass sport and thus changed views on the promotion of a healthy lifestyle among primary school pupils. This document laid the foundations for promoting a healthy personality implying a healthy mind in a healthy body. The first sub-stage - 1950-1959 is characterized by a transition to the new content of education, creation of new types of schools, after-school clubs. Such steps dramatically increased interest in promoting a healthy lifestyle among primary school pupils and brought some positive changes, namely, the beginning of experimental learning based on new programmes and textbooks; advanced training of teaching staff; improvement of younger pupils' sanitary and hygienic learning; the focusing of physical education on the promotion of a healthy lifestyle among primary school pupils.

The research finds that much attention has been paid to a rational organization of lessons (study/relax balance) to prevent overload. Such active forms as walks, games, physical exercises, sports play an essential role in promoting a healthy lifestyle.

The second sub-stage (1960-1969) involved an intensive development of physical education, mass sports and extracurricular activities, as well as an improvement of hygiene education, which influenced the promotion of a healthy lifestyle among younger schoolchildren. The main tasks of education were to develop new physical education programmes for primary school pupils (grades 1-4), retrain primary school teachers in the context of physical education methods, organize physical exercises before lessons and implement sanitary and hygienic rules for pupils.

In addition to positive changes, there were also negative trends, including the deterioration of primary school pupils' health, the inefficiency of forms and methods for promoting a healthy lifestyle among schoolchildren and non-systematic pedagogical activities aimed at teaching primary school pupils to care about their health.

The transformational stage (1970-1990) is caused by dramatic changes in the promotion of a healthy lifestyle among primary school pupils after reforms in primary school.

The first sub-stage (1970-1983) was aimed at updating the content, forms and methods of teaching and learning. Particular attention was paid to the restructuring of primary education. Given reforms in primary education (three-year education since 1971), the promotion of a healthy lifestyle among younger schoolchildren implied using the following health-promoting approaches in the educational process: the so-called "green lessons" (outside the classroom); active games during long breaks and in after-school clubs; music breaks during lessons, daily physical exercises; involvement of pupils in sports clubs and sections; installation of nonstandard sports equipment in school playgrounds.

The second sub-stage (1984-1990) was characterized by the main historical-and-pedagogical processes of the period under study, namely, reforms in primary education, which introduced four-year primary education (1984). The basic health-promoting tasks of primary school included creating optimal conditions for the full development of pupils; enhancing the role of physical development; eliminating overload and making educational material more understandable; updating school facilities, which should meet all age characteristics of primary school pupils; ensuring links between preschool and primary education. Besides, new programmes underwent significant transformations since differentiated educational standards and homework, aimed at promoting a healthy lifestyle and motor activity, were included in physical education programmes). Health-promoting objectives, defined by legal documents on education reforms, caused the need to improve the forms and methods, which would provide all pupils with systematic physical training in school and after-school time, and enhance the physical development of children and meet the requirements of school hygiene. The effective forms of working with schoolchildren in school time included compulsory health hours daily, physical exercises, morning gymnastics, physical activity breaks, active games, breaks. Important extracurricular forms promoting a healthy lifestyle among primary school pupils were hiking, walking, sports competitions, sports sections.

The negative trends in education at that time were as follows: schools' inability to implement reforms; ineffective use of individual forms and methods of working with six-year-old children who had difficulties in learning; insufficient provision of schools with medical specialists, which significantly decreased efficiency of preventive work and hygiene education of pupils. Also, one could observe a certain inability to systematically promote a values-based attitude towards a healthy lifestyle among pupils, as well as the irregular organization of pupils' motor activity during the educational process.

The leading trend of the updating stage (1991-2017: the first sub-stage - 1991-2001; the second sub-stage - 2002-2017) was the Declaration on State Sovereignty of Ukraine, which caused shifts in educational paradigms. The beginning and the end of this stage covered the adoption of the Laws of Ukraine "On Education" $(1991,2017)$, which became the basis for the introduction of new ideas, changes in the structure and content of curricula and programmes of primary education aimed at developing a healthy personality. 
The proclamation of Ukraine's independence resulted in the creation of certain favourable conditions for promoting a healthy lifestyle among schoolchildren in light of the adoption of new state standards on primary education (providing the necessary facilities; eliminating overload under psychophysiological factors in educational activities; organizing integrated learning based on gaming methods; establishing health-promoting centres and modern playgrounds and sports grounds; applying didactic tools aimed at promoting children's health).

Given its integration into the global educational space at that time, primary education witnessed a constant update of innovative approaches to promoting a healthy lifestyle of primary school pupils (frequent discussions on this problem at the state level; creation of a modern health-promoting educational space; integration and humanization of the educational process; expansion of the content, forms, and methods of working with primary school pupils).

It became vital to develop and scientifically justify innovative information technologies, forms, methods of work and elaborate educational programmes, textbooks and teaching aids for schools to promote a healthy lifestyle among primary school pupils. Innovative methods of working with primary school students included project activities, critical situations, analysis of social situations, portfolios, brainstorming.

Lessons and after-school time paid much attention to educational work (planning sessions, lectures, educational events, health days, health weeks, sports clubs classes; participation in competitions, such as "Cossack Fun", "Mini-Football", "Happy Sports Family", "Cheerleading") and physical education and health lessons (movement breaks, breathing exercises, gymnastics for eyes, psychological breaks, music therapy).

The main trends in the promotion of a healthy lifestyle among primary school pupils included the following: the increased attention to pupils' physical activity; the introduction of additional relaxing days during the working week; active implementation of health-promoting technologies in the educational process (related to physical education, recreation, hygiene); the creation of educational programmes aimed at preserving and promoting pupils' health; the enhancement of experimental research in primary education; the increasing impact of media and social networks on the overall health of the population.

Conclusions. Based on a systemic-and-historical approach and comparative analysis of health-promoting goals stated in legal documents, reports, analytical certificates, one can identify the following main factors in the promotion of a healthy lifestyle among primary school students in the period under study: socially-economic (European integration processes in education; the improvement of facilities in primary school (spatial environment, didactic tools, educational centres); educational (the elaboration of sectoral legal documents; the updating of primary education content; the introduction of research experimental work in primary education); medical and hygienic (compulsory medical examinations of pupils; the provision of hygiene and sanitary conditions in schools; the establishment of health care facilities, including child health centres, hygiene and public health centres); socio-cultural (the development of a values-based attitude towards health in children; promotion activities aimed at motivating pupils towards a healthy lifestyle).

The research proves that the promotion of a healthy lifestyle among primary school pupils is a complex process focused on the development of children's vital competency, their values-based attitude towards their health and the creation of necessary conditions for preserving and strengthening physical, mental, spiritual and social spheres of pupils' health in primary school.

This process covers the second half of the $20^{\text {th }}$ century - the early 21 st century and consists of the following stages:

Stage 1 (1950-1969) - the preparatory stage: the first sub-stage (1950-1959) is devoted to the sportization of physical education at school; the second sub-stage (1960-1969) - the improvement of sanitary and hygiene learning. The main trends include experimental learning based on new programmes and textbooks; the improvement of younger pupils' sanitary and hygienic learning; the focusing of physical education on the promotion of a healthy lifestyle among primary school pupils.

Stage 2 (1970-1990) - the transformational stage: the first sub-stage (1970-1983) is devoted to the expansion of forms and methods for promoting a healthy lifestyle among pupils; the second sub-stage (1984-1990) - the creation of educational environment aimed at promoting a healthy lifestyle. This stage is characterized by the following trends: the 1984 reforms in primary education (the introduction of four-year primary education); the introduction of standards on sport and fitness complex of primary education (1972); the establishment of new educational establishments, such as "School-Kindergarten" (the early 1980s); the promotion of valeologically conscious personality.

Stage 3 (1991-2017) - the updating stage: the first sub-stage (1991-2001) is devoted to the updating of primary education content; the second sub-stage (2002-2017) - the promotion of a healthy lifestyle among schoolchildren under the conditions of educational changes. This period is characterized by the following trends: the establishment of health promotion schools; the creation of health-promoting environment; the implementation of experimental research work in primary education; the elaboration of programmes aimed at preserving and promoting pupils' health; active introduction of health-promoting technologies into the educational process (related to physical education, recreation, hygiene).

The main trends that determined structural changes in the promotion of a healthy lifestyle among primary school pupils in the second half of the $20^{\text {th }}$ century - the early 21 st century are as follows: structural and organizational - the organization of physical activities in after-school clubs; the provision of balanced nutrition through modernizing and constructing school canteens; contentrelated - the updating of the content and structure of primary education to ensure full development of children following their age and psychophysiological characteristics; the establishment of health promotion schools; educational and technological - the introduction of innovative technologies and methods (project-related health-promoting technologies, personality-oriented training, Yefymenko's technology, learning in motion); informational and educational - educational work (promotional speeches, organization of health months, health and sports days, meetings with doctors, athletes, coaches, psychologists).

The research highlights the ideas of effective historical-and-pedagogical experience in promoting a healthy lifestyle among primary school pupils, which teachers can use to improve the educational process in secondary schools.

The research finds that the promising areas for improving the promotion of a healthy lifestyle among primary school pupils are the following: the increase of pupils' physical activity during the educational process (daily health hours and after-school clubs; 
morning gymnastics, complex physical exercises of different intensity, participation in wellness challenges, CrossFit competitions); the cooperation with associations and public organizations through a series of activities aimed at promoting a healthy lifestyle among pupils (health-promoting marathons and actions; social health programmes); the creation of projects on social partnership within the school and educational environment aimed at promoting health (the establishment of special councils for promoting a healthy lifestyle); monitoring of pupils' motivation to care for their health, physical development and activity; the development and implementation of a system of lifelong education on children's health and lifestyle (video blogging, lifehacking, pedagogical coaching, workshops).

The scientific value of the research covers the following: for the first time, a scientific pedagogical problem of developing theory and practice in promoting a healthy lifestyle in primary education in the second half of the $20^{\text {th }}$ century - the early 21 st century has been studied; the author's periodization of promoting a healthy lifestyle in primary school in the second half of the $20^{\text {th }}$ century the early 21st century (Stage 1 (1950-1969) - the preparatory stage (the first sub-stage - 1950-1959; the second sub-stage - 19601969); Stage 2 (1970-1990) - the transformational stage (the first sub-stage - 1970-1983; the second sub-stage - 1984-1990); Stage 3 (1991-2017) - the updating stage (the first sub-stage - 1991-2001; the second sub-stage - 2002-2017) has been justified; the factors influencing the promotion of a healthy lifestyle among primary school pupils, which include socially-economic factors (European integration processes in education; the improvement of facilities in primary school (spatial environment, didactic tools, educational centres); educational factors (the elaboration of sectoral legal documents; the updating of primary education content; the introduction of research experimental work in primary education); medical and hygienic factors (compulsory medical examinations of pupils; the provision of hygiene and sanitary conditions in schools; the establishment of health care facilities, including child health centres, hygiene and public health centres); socio-cultural factors (the development of a values-based attitude towards health in children; promotion activities aimed at motivating pupils towards a healthy lifestyle), have been identified; the trends which caused the promotion of a healthy lifestyle among primary school pupils in the second half of the $20^{\text {th }}$ century - the early 21 st century (structural and organizational - the organization of physical activities in after-school clubs; the provision of balanced nutrition through modernizing and constructing school canteens; content-related - the updating of the content and structure of primary education with the aim to ensure full development of children in accordance with their age and psychophysiological characteristics; the establishment of health promotion schools; educational and technological - the introduction of innovative technologies and methods (project-related health-promoting technologies, personality-oriented training, Yefymenko's technology, learning in motion); informational and educational - educational work (promotional speeches, organization of health months, health and sports days, meetings with doctors, athletes, coaches, psychologists) have been revealed; the prospects of using innovative experience in promoting a healthy lifestyle among primary school pupils in modern schools (the increase of pupils' physical activity through the introduction of innovative forms of work; the establishment of cooperation with associations and public organizations, the in troduction of projects on social partnership aimed at promoting health among schoolchildren) have been determined; such concepts as "health", "healthy lifestyle" and "promotion of a healthy lifestyle among primary school pupils" have been defined; the provisions revealing the system of promoting a healthy lifestyle among primary school pupils have been further developed; little-known documents, historical facts and information about promoting a healthy lifestyle among primary school pupils, based on identified archival materials, in particular, the State Archives of Kherson Oblast - repositories 3706, 2239, 2004; the Central State Archives of Higher Authorities and Administration of Ukraine, Kyiv - repository 166.

The practical value of the research consists in the fact that its results are reflected in the specialized course, titled "A Healthy Lifestyle - a Healthy Nation" and methodological recommendations, titled "The Content, Forms and Methods of Promoting a Healthy Lifestyle among Schoolchildren: A Historical and Pedagogical Retrospective". Research findings can be used by higher education institutions to train primary and physical education teachers, as well as can be implemented in the system of postgraduate education and the organization of working with secondary school teachers.

\section{References}

1.Babych, V. M. (2006). Training future physical education teachers for developing health culture in pupils. (PhD thesis). Taras Shevchenko Luhansk National Pedagogical University, Luhansk.

2.Pivnenko, Yu. V. (2013). Developing physical health in the educational process of primary school. (PhD thesis). Zaporizhzhia Regional Institute of Postgraduate Pedagogical Education, Zaporizhzhia.

3.Pysarchuk, O. T. (2014). Promoting the educational and cognitive activity of younger pupils in the educational environment: the problems and solutions. Science and Education a New Dimension. Pedagogy and Psychology, 2 (10), 90-93.

4.Vashchenko, O. O. (2007). Developing health skills in pupils in 1-4 grades from boarding schools. (PhD thesis). The Institute for Problems of Character Building of the Academy of Pedagogical Sciences of Ukraine, Kyiv.

5.Yankovych, O. I. (2017). Developing health-promoting technologies in the educational process of primary school (19912016). Human Studies. Pedagogy, 4 (36), 301-312.

6.Roshchin, I. H. (2015). General physical education of pupils in secondary school: the history, theory, practice (the late 19th century - the early 21st century). Kherson: Kherson Academy of Lifelong Education.

7.Chyzhyk, T. H. (2018). The organizational and pedagogical principles of physical training for younger pupils (19471991). (PhD thesis). Kherson Academy of Lifelong Education, Kherson.

8.Dubohai, O. D. (2006). Physical education as a component of the child's health and educational attainment. Kyiv: School World.

9.Moiseiev, S. O. (2009). Personality-oriented physical education of high school students. Kherson: RIPO.

10. Shyian, O. I. (2008). The essence of the state education policy on promoting a healthy lifestyle among young people. Public Administration: Theory and Practice, 2. Retrieved from http://www.nbuv.gov.ua/e-journals/dutp/2008-2/doc_pdf/shyjan.pdf.

11. Zakopailo, S. A. (2003). Pedagogical principles of promoting a healthy lifestyle among boys in grades 10-11. (PhD thesis). The Institute for Problems of Character Building of the Academy of Pedagogical Sciences of Ukraine, Kyiv. 
12. Zubalii, M. (2000). The components of a healthy lifestyle. Deputy Principal, 20, 29.

13. Akhverdova, O. A. (2004). Differential psychology. Theoretical and applied aspects of the study on integral personality. Saint Petersburg: Speech.

14. Amosov, N. M. (1987). Thoughts on health. Moscow: Physical Education and Sport.

15. Apanasenko, H. L., \& Dolzhenko, L. P. (2007). The level of health and physiological reserves of the body. Theory and Methodology of Physical Education and Sports, 1, 17-21.

16. Brekhman, I. I. (1990). Valeology as a science about health (2nd ed.). Moscow: Physical Culture and Sports.

17. Hundarov, M. A. (1999). Medical and social problems of a healthy lifestyle. Kyiv: IZMN. Education.

18. Khripkova, A. G., Antropova, M. V., \& Farber, D. A. (1990). Age-related physiology and school hygiene. Moscow:

19. Kondratiuk, S. M. (2003). An integrative approach to promoting a healthy lifestyle among younger pupils. (PhD thesis). The Institute for Problems of Character Building of the Academy of Pedagogical Sciences of Ukraine, Kyiv.

20. Chernii, V. P. (2014). Promoting a healthy lifestyle among younger pupils (the second half of the 20th century - the early 21st century). (PhD thesis). Volodymyr Vynnychenko Kirovohrad State University, Kirovohrad.

21. Idrisova, N. O. (2012). The concept of "a healthy lifestyle" as a social and values-based category. Scientific Notes of M. P. Drahomanov National Pedagogical University: Pedagogical and Historical Sciences, 108, 56-63.

22. Pienov, V. V. (2017). Developing valeological education in the south of Ukraine (the late 19th century - the second half of the 20th century). (PhD thesis). Volodymyr Vynnychenko Kirovohrad State University, Kirovohrad.

23. Sukhomlynska, O. V. (2012). O. Sukhomlynskyi's thoughts on children's health from the historical perspective. Native School, 7, 3-7.

24. Yermakova, T. S. (2008). The characteristics of promoting a healthy lifestyle among schoolchildren: the historical aspect. Pedagogy, Psychology and Medical and Biological Problems of Physical Education and Sports, 8, 60-62.

25. Maksymchuk, B., Gurevych, R., Matviichuk, T., Surovov, O., Stepanchenko, N., Opushko, N., Sitovskyi, A., Kosynskyi, E., Bogdanyuk, A., Vakoliuk, A., Solovyov, V., \& Maksymchuk, I. (2020a). Training Future Teachers to Organize School Sport. Revista Romaneasca Pentru Educatie Multidimensionala, 12(4), 310-327. https://doi.org/10.18662/rrem/12.4/347

26. Palamarchuk, O., Gurevych, R., Maksymchuk, B., Gerasymova, I., Fushtey, O., Logutina, N., Kalashnik, N., Kylivnyk, A., Haba, I., Matviichuk, T., Solovyov, V., \& Maksymchuk, I. (2020). Studying Innovation as the Factor in Professional SelfDevelopment of Specialists in Physical Education and Sport. Revista Romaneasca Pentru Educatie Multidimensionala, 12(4), 118136. https://doi.org/10.18662/rrem/12.4/337

27. Onishchuk, I., Ikonnikova, M., Antonenko, T., Kharchenko, I., Shestakova, S., Kuzmenko, N., \& Maksymchuk, B. (2020). Characteristics of Foreign Language Education in Foreign Countries and Ways of Applying Foreign Experience in Pedagogical Universities of Ukraine. Revista Romaneasca Pentru Educatie Multidimensionala, $12(3), 44-65$. https://doi.org/10.18662/rrem/12.3/308

28. Maksymchuk, B., Matviichuk, T., Solovyov, V., Davydenko, H., Soichuk, R., Khurtenko, O., Groshovenko, O., Stepanchenko, N., Andriychuk, Y., Grygorenko, T., Duka, T., Pidlypniak, I., Gurevych, R., Kuzmenko, V., \& Maksymchuk, I. (2020b). Developing Healthcare Competency in Future Teachers. Revista Romaneasca Pentru Educatie Multidimensionala, 12(3), 24-43. https://doi.org/10.18662/rrem/12.3/307

29. Gerasymova, I., Maksymchuk, B., Bilozerova, M., Chernetska, Yu., Matviichuk, T., Solovyov, V., \& Maksymchuk, I. (2019). Forming professional mobility in future agricultural specialists: the sociohistorical context. Revista Romaneasca pentru Educatie Multidimensionala, 11 (4), 345-361. http://lumenpublishing.com/journals/index.php/rrem/article/view/1604/pdf

30. Sheremet M., Leniv Z., Loboda V., Maksymchuk B. (2019) The development level of smart information criterion for specialists' readiness for inclusion implementation in education. Information Technologies and Learning Tools, 72, $273-285$. https://journal.iitta.gov.ua/index.php/itt//article/view/2561

31. Nerubasska, A., Maksymchuk, B. (2020a). The Demarkation of Creativity, Talent and Genius in Humans: a Systemic Aspect. Postmodern Openings, 11 (2), 240-255. https://www.lumenpublishing.com/journals/index.php/po/article/view/2625

32. Melnyk, N., Bidyuk, N., Kalenskyi, A., Maksymchuk. B., Bakhmat, N., Matviienko, O. ... Maksymchuk, I. (2019). Models and organizational characteristics of preschool teachers' professional training in some EU countries and Ukraine. Zbornik Instituta za pedagoska istrazivanja, 51 (1), 46-93. https://ipisr.org.rs/images/pdf/zbornik-51/Natalija-Meljnik.pdf

33. Bakhmat, N., Maksymchuk, B., Voloshyna, O., Kuzmenko, V., Matviichuk, T., Kovalchuk, A. ... Maksymchuk, I. (2019). Designing cloud-oriented university environment in teacher training of future physical education teachers. Journal of Physical Education and Sport, 19 (4), 1323-1332. http://efsupit.ro/images/stories/august2019/Art\%20192.pdf

34. Behas, L., Maksymchuk, B., Babii, I., Tsymbal-Slatvinska, S., Golub, N., Golub, V. ... Maksymchuk, I. (2019). The influence of tempo rhythmic organization of speech during gaming and theatrical activities on correction of stammering in children. Journal of Physical Education and Sport, 19 (4), 1333-1340. http://efsupit.ro/images/stories/august2019/Art\%20193.pdf

35. Bezliudnyi O., Kravchenko O., Maksymchuk B., Mishchenko M., Maksymchuk, I. (2019) Psycho-correction of burnout syndrome in sports educators (2019). Journal of Physical Education and Sport, 19 (3), Art 230 pp. 1585. http://efsupit.ro/images/stories/septembrie2019/Art\%20230.pdf

36. Halaidiuk, M., Maksymchuk, B., Khurtenko, O., Zuma, I., Korytko, Z., Andrieieva, R. ... Maksymchuk, I. (2018). Teaching approaches in extracurricular physical activities for 12-14-year-old pupils under environmentally unfavourable conditions. Journal of Physical Education and Sport, 18 (4), 2284-2291. http://efsupit.ro/images/stories/decembrie2018/Art\%20344.pdf

37. Maksymchuk, I., Maksymchuk, B., Frytsiuk, V., Matviichuk, T., Demchenko, I., Babii, I. ... Savchuk, I. (2018). Developing pedagogical mastery of future physical education teachers in higher education institutions. Journal of Physical Education and Sport, 18 (2), 810-815. http://efsupit.ro/images/stories/iunie2018/Art\%20119.pdf 


\section{Література}

1.Бабич В. М. Підготовка майбутніх учителів фізичного виховання до формування культури здоров'я школярів : дис. ... канд. пед. наук : 13.00.04 / Луганський нац. пед. ун-т ім. Тараса Шевченка. Луганськ, 2006. 315 с.

2.Півненко Ю. В. Формування фізичного здоров'я у навчально-виховному процесі початкової школи : дис. ... канд. пед. наук : 13.00.07 / Запорізький обл. ін-т післядипломної пед. освіти. Запоріжжя, 2013. 215 с.

3.Писарчук О. Т. Активізація навчально-пізнавальної діяльності молодших школярів в умовах освітньорозвивального середовища: проблеми і шляхи розв'язання. Sciens and Education a New Dimension. Pedagogy and Phsychology. Budapest, 2014. T. 2 (10), issue 20. C. 90-93.

4.Ващенко О.О. Формування умінь і навичок здорового способу життя учні 1-4 класів шкіл-інтернатів: дис. ... канд. пед. наук. 13.00.07. / 2007. 385 с.

5.Янкович О. І. Розвиток здоров'язбережувальних технологій у навчально-виховному процесі початкової школи (1991-2016 рр.). Людинознавчі студії. Педагогіка : збірник наукових праць / Дрогобицький держ. пед. ун-т ім. І. Франка. Дрогобич, 2017. Вип. 4/36. С. 301312 . http://nbuv.gov.ua/UJRN/Lstud_2017_4_32 (дата звернення 02.12.2018).

6.Рощін І. Г. Загальна фрізична підготовка учнів ЗОШ: історія, теорія, практика (кінець XIX - початок XXI століть) : монографрія. Херсон. 2015. 344 с.

7.Чижик Т. Г. Організаційно-педагогічні засади фізичної підготовки молодших школярів (1947-1991рр. : дис. ... канд. пед. наук : 13.00 .01 / КВН3 «Херсонська академія неперервної освіти»; Тернопільський нац. пед. ун-т ім. В. Гнатюка. Херсон ; Тернопіль, 2018. 270 с.

8.Дубогай О. Д. Фізкультура як складова здоров'я та успішності навчання дитини. Київ : Шкільний світ, 2006. 128 с.

9.Моїсеєв С. О. Особистісно орієнтоване фрізичне виховання старшокласників загальноосвітньої школи: монографія / за ред. В. В. Кузьменка. Херсон : РІПО, 2009.153 с.

10. Шиян О. І. Сутність державної освітньої політики з питань забезпечення здорового способу життя молоді. Державне управління: теорія та практика. 2008. № 2. URL: http://www.nbuv.gov.ua/e-journals/dutp/2008-2/doc_pdf/shyjan.pdf (дата звернення 12.05.2017).

11. Закопайло С. А. Педагогічні основи виховання в юнаків 10-11 класів цінностей здорового способу життя : автореф. дис. ... канд. пед. наук : 13.00.07 / Ін-т проблем виховання АПН України. Київ, 2003. 19 с.

12. Зубалій М. Складові здорового способу життя. Завуч. 2000. № 20. С. 29.

13. Ахвердова О. А. Дифференциальная психология. Теоретические и прикладные аспекты исследования интегральной индивидуальности : учеб. пособие. Санкт-Петербург : Речь, 2004. 168 с.

14. Амосов Н. М. Раздумья о здоровье. М.: Физкультура и спорт, 1987. 178 с.

15. Апанасенко Г. Л., Долженко Л. П. Рівень здоров'я і фізіологічні резерви організму. Теорія і методика фрізичного виховання і спорту. 2007. № 1. С. 17-21.

16. Брехман И. И. Валеология - наука о здоровье. 2-е изд., доп. и перераб. Москва : Физкультура и спорт, 1990.

208 c.

17. Гундаров М. А. Медико-соціальні проблеми здорового способу життя. Київ : ІЗМН, 1999. 83 с.

18. Хрипкова А. Г., Антропова М. В., Фарбер Д. А. Возрастная физиология и школьная гигиена. Москва : Просвещение, 1990. 320 с.

19. Кондратюк С. М. Інтегративний підхід до виховання у молодших школярів здорового способу життя : дис. ... канд. пед. наук : 13.00.07 / Ін-т проблем виховання АПН України. Київ, 2003. 200 с.

20. Черній В. П. Формування у молодших школярів здорового способу життя (друга половина XX - початок XXI століття) : дис. ... канд. пед. наук : 13.00.01 / Кіровоградський держ. пед. ун-т ім. В. Винниченка Кіровоград, 2014.

21. Ідрісова Н. О. Поняття «Здоровий спосіб житяя як соціально-ціннісна категорія. Наукові записки Національного педагогічного університету імені М. П. Драгоманова. Серія: Педагогічні та історичні науки. Київ : Вид-во НПУ ім. М. П. Драгоманова, 2012. Вип. 108. С. 56-63.

22. Пєнов В. В. Розвиток валеологічної освіти на півдні України (кінець XIX - друга половина XX століття) : дис. ... канд. пед. наук : 13.00.01 / Кіровоградський держ. пед. універ. Кіровоград, 2017. 241 с.

23. Сухомлинська О. В. Думки В. О. Сухомлинського про здоров'я дітей в історичній перспективі. Рідна школа. 2012. № 7. С. 3-7.

24. Єрмакова Т. С. Особливості фрормування здорового способу життя школярів: історичний аспект. Педагогіка, психологія та медико-біологічні проблеми фрізичного виховання і спорту. 2008. № 8. С. 60-62.

25. Maksymchuk, B., Gurevych, R., Matviichuk, T., Surovov, O., Stepanchenko, N., Opushko, N., Sitovskyi, A., Kosynskyi, E., Bogdanyuk, A., Vakoliuk, A., Solovyov, V., \& Maksymchuk, I. (2020a). Training Future Teachers to Organize School Sport. Revista Romaneasca Pentru Educatie Multidimensionala, 12(4), 310-327. https://doi.org/10.18662/rrem/12.4/347

26. Palamarchuk, O., Gurevych, R., Maksymchuk, B., Gerasymova, I., Fushtey, O., Logutina, N., Kalashnik, N., Kylivnyk, A., Haba, I., Matviichuk, T., Solovyov, V., \& Maksymchuk, I. (2020). Studying Innovation as the Factor in Professional SelfDevelopment of Specialists in Physical Education and Sport. Revista Romaneasca Pentru Educatie Multidimensionala, 12(4), 118136. https://doi.org/10.18662/rrem/12.4/337

27. Onishchuk, I., Ikonnikova, M., Antonenko, T., Kharchenko, I., Shestakova, S., Kuzmenko, N., \& Maksymchuk, B. (2020). Characteristics of Foreign Language Education in Foreign Countries and Ways of Applying Foreign Experience in Pedagogical Universities of Ukraine. Revista Romaneasca Pentru Educatie Multidimensionala, $12(3), 44-65$. https://doi.org/10.18662/rrem/12.3/308

28. Maksymchuk, B., Matviichuk, T., Solovyov, V., Davydenko, H., Soichuk, R., Khurtenko, O., Groshovenko, O., Stepanchenko, N., Andriychuk, Y., Grygorenko, T., Duka, T., Pidlypniak, I., Gurevych, R., Kuzmenko, V., \& Maksymchuk, I. (2020b). 
Developing Healthcare Competency in Future Teachers. Revista Romaneasca Pentru Educatie Multidimensionala, 12(3), 24-43. https://doi.org/10.18662/rrem/12.3/307

29. Gerasymova, I., Maksymchuk, B., Bilozerova, M., Chernetska, Yu., Matviichuk, T., Solovyov, V., \& Maksymchuk, I. (2019). Forming professional mobility in future agricultural specialists: the sociohistorical context. Revista Romaneasca pentru Educatie Multidimensionala, 11 (4), 345-361. http://lumenpublishing.com/journals/index.php/rrem/article/view/1604/pdf

30. Sheremet M., Leniv Z., Loboda V., Maksymchuk B. (2019) The development level of smart information criterion for specialists' readiness for inclusion implementation in education. Information Technologies and Learning Tools, 72, 273-285. https://journal.iitta.gov.ua/index.php/itt//article/view/2561

31. Nerubasska, A., Maksymchuk, B. (2020a). The Demarkation of Creativity, Talent and Genius in Humans: a Systemic Aspect. Postmodern Openings, 11 (2), 240-255. https://www.lumenpublishing.com/journals/index.php/po/article/view/2625

32. Melnyk, N., Bidyuk, N., Kalenskyi, A., Maksymchuk. B., Bakhmat, N., Matviienko, O. ... Maksymchuk, I. (2019). Models and organizational characteristics of preschool teachers' professional training in some EU countries and Ukraine. Zbornik Instituta za pedagoska istrazivanja, 51 (1), 46-93. https://ipisr.org.rs/images/pdf/zbornik-51/Natalija-Melinik.pdf

33. Bakhmat, N., Maksymchuk, B., Voloshyna, O., Kuzmenko, V., Matviichuk, T., Kovalchuk, A. ... Maksymchuk, I. (2019). Designing cloud-oriented university environment in teacher training of future physical education teachers. Journal of Physical Education and Sport, 19 (4), 1323-1332. http://efsupit.ro/images/stories/august2019/Art\%20192.pdf

34. Behas, L., Maksymchuk, B., Babii, I., Tsymbal-Slatvinska, S., Golub, N., Golub, V. ... Maksymchuk, I. (2019). The influence of tempo rhythmic organization of speech during gaming and theatrical activities on correction of stammering in children. Journal of Physical Education and Sport, 19 (4), 1333-1340. http:/lefsupit.ro/images/stories/august2019/Art\%20193.pdf

35. Bezliudnyi O., Kravchenko O., Maksymchuk B., Mishchenko M., Maksymchuk, I. (2019) Psycho-correction of burnout syndrome in sports educators (2019). Journal of Physical Education and Sport, 19 (3), Art 230 pp. 1585. http://efsupit.ro/images/stories/septembrie2019/Art\%20230.pdf

36. Halaidiuk, M., Maksymchuk, B., Khurtenko, O., Zuma, I., Korytko, Z., Andrieieva, R. ... Maksymchuk, I. (2018). Teaching approaches in extracurricular physical activities for 12-14-year-old pupils under environmentally unfavourable conditions. Journal of Physical Education and Sport, 18 (4), 2284-2291. http://efsupit.ro/images/stories/decembrie2018/Art\%20344.pdf

37. Maksymchuk, I., Maksymchuk, B., Frytsiuk, V., Matviichuk, T., Demchenko, I., Babii, I. ... Savchuk, I. (2018). Developing pedagogical mastery of future physical education teachers in higher education institutions. Journal of Physical Education and Sport, 18 (2), 810-815. http://efsupit.ro/images/stories/iunie2018/Art\%20119.pdf

DOI 10.31392/NPU-nc.series 15.2021.3(133).02

Анікіна I. В.

кандидат філологічних наук, доцент кафедри слов'янських мов та зарубіжної літератури, Уманський державний педагогічний університет імені Павла Тичини Онішук I. I. кандидат педагогічних наук, старший викладач кафедри методики навчання іноземних мов, Вінницький державний педагогічний університету ім. М. Коцюбинського Преснер Р. Б. кандидат педагогічних наук, доцент, Національний лісотехнічний університет України Осіпчук O.B.

викладач кафедри іноземних мов, ПВНЗ "Міжнародний економіко-гуманітарний університет імені академіка Степана Дем'янчука" Турчин A.I. кандидат педагогічних наук, доцент кафедри іноземних мов, Тернопільський національний педагогічний університет імені Володимира Гнатюка Поченюк Я. В.

Старший викладач кафедри романо-германської філології, ПВНЗ «Міжнародний економіко-гуманітарний університет імені академіка Степана Дем'янчука»

\section{ПРОБЛЕМИ ІНШОМОВНОЇ ОСВІТИ МАЙБУТНІХ ПЕДАГОГІВ У КОНТЕКСТІ ПОШУКУ НОВОЇ МОДЕЛІ ГУМАНІТАРНОЇ ОСВITИ}

Важливим для дослідження проблеми іншомовної освіти майбутніх вчителів гуманітарних спеціальностей у $X X$ столітті виявився пошук нової моделі гуманітарної освіти, спрямування ї̈ на формування системи цінностей, духовних орієнтирів і соціальних норм, котрі визначають динаміку розвитку людської цивілізації, що поставило нові вимоги до рівня та ефективності іншомовної освіти. Аналіз стандартів, що застосовуються в зарубіжній практиці іншомовної освіти, дозволяє визначити категорії іншомовних знань і навичок, котрі необхідно відобразити в документах, що розробляються в Україні. Використання міжнародного досвіду щодо стандартизації педагогічної діяльності з іншомовної освіти та розробки кваліфрікаційних вимог, професійних стандартів та сертифрікаційних процедур, діагностичних методик оцінки та самооцінки педагогічної діяльності з іноземної мови, можуть використовуватися в процесі модернізації практики викладання іншомовної освіти майбутніх учителів гуманітарних спеціальностей у педагогічних університетах України. Іншомовну освіту майбутніх учителів гуманітарних спеціальностей розуміємо як процес $i$ 